\title{
INTEGRASI STRATEGI CONCEPTUAL CHANGE DALAM MODEL PEMBELAJARAN INOVATIF UNTUK MENINGKATKAN KOMPETENSI PROFESIONAL GURU KIMIA KABUPATEN BLITAR
}

\author{
Oleh: \\ Harun Nasrudin', Utiya Azizah², Bertha Yonata ${ }^{3}$ \\ 1,2,3 Jurusan Kimia FMIPA Unesa \\ 1harunnasrudin@unesa.ac.id
}

\begin{abstract}
Abstrak
Telah dilakukan kegiatan pelatihan pengabdian kepada masyarakat (PKM) di Kabupaten Blitar yang bertujuan untuk mendeskripsikan pemahaman guru kimia terhadap materi integrasi strategi conceptual change dalam model-model pembelajaran inovatif, kemampuan guru kimia dalam menyusun kegiatankegiatan pembelajaran berbasis integrasi strategi conceptual change dalam model-model pembelajaran inovatif, dan respon guru selama mengikuti kegiatan pelatihan. Langkah-langkah kegiatan pelatihan yang dilakukan adalah penyegaran materi dan penyusunan Rencana Pelaksanaan Pembelajaran (RPP) yang mengintegrasikan strategi conceptual change dalam model-model pembelajaran inovatif. Evaluasi dilakukan melalui tes pemahaman dan angket kepada guru untuk mendapatkan data terhadap pelaksanaan pelatihan. Berdasarkan data hasil pelatihan, dapat disimpulkan bahwa: (1) pemahaman materi integrasi strategi conceptual change dalam model-model pembelajaran inovatif guru kimia di Kabupaten Blitar telah memperoleh kategori baik dan sangat baik, (2) kemampuan guru kimia di Kabupaten Blitar dalam menyusun kegiatan-kegiatan pembelajaran berbasis integrasi strategi conceptual change dalam model-model pembelajaran inovatif adalah baik dan sangat baik, dan (3) secara umum respon guru MGMP kimia di Kabupaten Blitar terhadap kegiatan pelatihan ini adalah baik dan sangat baik.
\end{abstract}

Kata Kunci: Pelatihan, Conceptual Change, Model Pembelajaran Inovatif, Peningkatan Kompetensi

\begin{abstract}
A community service have been done in Blitar which aimed to describe the understanding of chemistry teachers on the material the integration of conceptual change strategy in innovative learning models, the chemistry teacher's ability in developing learning activities based on integration of conceptual change strategy in the innovative learning models, and the responses teacher during the training activities. The steps of the training activities are the refreshing of the material and the preparation of the Lesson Plans that integrate the conceptual change strategy in innovative learning models. Evaluation is done through teacher's comprehension test and questionnaire to get data on training implementation. Based on the results of the training data, it can be concluded that: (1) the understanding of material of conceptual change strategy integration in innovative learning models of chemistry teacher in Blitar has obtained good and excellent category, (2) the ability of chemistry teacher in Blitar to develop learning activities based on the integration of conceptual change strategy in innovative learning models are good and excellent, and (3) the general response of chemistry teacher in Blitar to this training activity is good and very good.
\end{abstract}

Keywords: Training, Conceptual Change, Innovative Learning Models, Increased Competence

\section{PENDAHULUAN}

Pendidikan merupakan salah satu aspek yang berpengaruh terhadap kemajuan bangsa untuk meningkatkan mutu sumber daya manusia. Hal ini dikarenakan pendidikan memiliki peran yang signifikan dan bahkan masih menjadi pranata utama dalam penyiapan sumber daya manusia (Wagiran, 2007). Pemerintah Indonesia dengan giat menyusun dan mengembangkan program untuk meningkatkan mutu pendidikan, salah satunya dengan penyempurnaan kurikulum.

Guru merupakan salah satu faktor penting dalam implementasi kurikulum (Rohman, 2012). Sebagai tenaga professional, guru bertugas merencanakan, melaksanakan proses pembelajaran, dan menilai hasil pembelajaran mulai dari pendidikan anak usia 
dini jalur pendidikan formal, pendidikan dasar sampai dengan pendidikan menengah (Undang-undang Nomor 20 tahun 2003).

Proses pembelajaran dengan penekanan peserta didik belajar aktif ini sangat penting dan perlu dikembangkan karena keaktifan peserta didik akan membantunya untuk berdiri sendiri dalam kehidupan kognitifnya. Peserta didik juga akan terbantu menjadi orang kritis dalam menganalisis suatu hal karena selalu aktif berpikir dalam membangun pengetahuannya. Guru juga harus sadar bahwa peserta didik telah memiliki konsepsi awal (prakonsepsi) dalam membangun pengetahuannya.

Belajar merupakan pemahaman suatu ide baru, menilai kebenaran ide dan konsistennya dengan ide yang lain. Anggapan dasarnya adalah bahwa konsepsi awal (prakonsepsi) yang dibawa oleh peserta didik berpengaruh pada kemampuan untuk belajar dan berpengaruh pada ide yang akan dipelajari. Oleh karena itu, diperlukan suatu strategi pembelajaran conceptual change yang dimulai dengan menggali terlebih dahulu konsepsi-konsepsi peserta didik sebelum mengikuti pembelajaran di kelas dan menuntut peserta didik untuk menyempurnakan pengetahuan yang sudah dimiliki serta merubah, menyusun ulang atau mengganti pengetahuan yang sudah dimiliki tetapi salah dengan pengetahuan baru yang benar. Hal tersebut sesuai dengan pendapat Cakir (2008) bahwa strategi conceptual change digambarkan sebagai assimilasi, yaitu perubahan konsep-konsep baru pada pengetahuan yang telah ada dan sebagai akomodasi yaitu penyusunan ulang dan penggantian ide baru dengan konsep yang lebih tepat.

Penerapan strategi conceptual change ini diharapkan dapat mengubah konsepsi peserta didik melalui asimilasi dan restrukturisasi konsep. Dengan asimilasi konsep dan informasi baru ke dalam struktur kognitif yang sedang konflik (konflik kognitif), peserta didik diharapkan dapat mencabut konsepsi yang salah dari sistem akomodasinya dan menggantinya dengan konsep yang benar.

Mengingat pentingnya strategi conceptual change dari konsepsi awal (prakonsepsi) peserta didik pada proses pembelajaran dan untuk menciptakan proses akomodasi kognitif tersebut, maka strategi conceptual change harus diintegrasikan ke dalam model-model pembelajaran inovatif yang diimplementasikan. Sesuai dengan
Permendikbud tentang Standar Proses Pendidikan Dasar dan Menengah (Permendikbud nomor 22, 2016), kegiatan pembelajaran sepenuhnya diarahkan pada pengembangan ranah pengetahuan, keterampilan, dan sikap secara utuh melalui pendekatan saintifik dan diperkuat dengan penerapan model pembelajaran inovatif berbasis penyingkapan/penelitian (discovery/inquiry learning), pembelajaran berbasis proyek (project based learning), dan pembelajaran berbasis pemecahan masalah (problem based learning).

\section{METODE PELAKSANAAN}

Khalayak sasaran dalam kegiatan PKM ini adalah para guru kimia SMA/MA/SMK yang terlibat dalam MGMP Kimia di kabupaten Blitar.

Dari berbagai metode kegiatan yang dapat dipilih dalam kegiatan PKM, dengan memperhatikan berbagai pertimbangan, maka tim PKM memilih metode kegiatan sebagai berikut.

1. Pembelajaran antara tim PKM dan guruguru dalam MGMP Kimia di Kabupaten Blitar dalam rangka penyegaran materi integrasi strategi Conceptual Change dalam model-model pembelajaran inovatif.

2. Tim PKM membimbing guru-guru dalam MGMP Kimia di Kabupaten Blitar melaksanakan kegiatan penyusunan Rencana Pelaksanaan Pembelajaran (RPP) yang mengintegrasikan strategi Conceptual Change dalam model-model pembelajaran inovatif, dalam rangka mendapatkan data:

a. Kemampuan guru MGMP Kimia di Kabupaten Blitar dalam menyusun kegiatan-kegiatan pembelajaran integrasi strategi Conceptual Change dalam model-model pembelajaran inovatif.

b. Pemahaman guru MGMP Kimia di Kabupaten Blitar terhadap materi integrasi strategi Conceptual Change dalam model-model pembelajaran inovatif.

Tim PKM memberikan angket kepada peserta untuk mendapatkan data respon peserta terhadap pelaksanaan pelatihan integrasi strategi Conceptual Change dalam model-model pembelajaran inovatif. 


\section{HASIL DAN PEMBAHASAN}

Hasil pemahaman guru MGMP Kimia di Kabupaten Blitar setelah pembelajaran dalam rangka penyegaran tentang materi modelmodel pembelajaran inovatif dan strategi conceptual change untuk memperbaiki miskonsepsi diperoleh melalui data tes Pemahaman integrasi strategi Conceptual Change dalam Model-model Pembelajaran Inovatif disajikan pada Tabel 1.

Tabel 1. Pemahaman Peserta terhadap Materi Integrasi Strategi Conceptual Change dalam Model-Model Pembelajaran Inovatif

\begin{tabular}{|c|c|c|c|c|c|}
\hline \multirow{2}{*}{ No. } & \multirow{2}{*}{ Uraian } & \multicolumn{2}{|c|}{ Jawaban } & \multicolumn{2}{|c|}{ Kategori } \\
\hline & & Pretes & Postes & Pretes & Postes \\
\hline 1 & $\begin{array}{l}\text { Pemahaman tentang pengertian } \\
\text { strategi conceptual change }\end{array}$ & $\begin{array}{c}\text { Paham } / \text { Jelas } \\
33,33 \%\end{array}$ & $\begin{array}{c}\text { Paham/Jelas } \\
100 \%\end{array}$ & Buruk & $\begin{array}{c}\text { Sangat } \\
\text { Baik }\end{array}$ \\
\hline 2 & $\begin{array}{l}\text { Pemahaman tentang pengertian } \\
\text { model-model pembelajaran } \\
\text { inovatif }\end{array}$ & $\begin{array}{c}\text { Paham/Jelas } \\
33,33 \%\end{array}$ & $\begin{array}{l}\text { Paham/Jelas } \\
83,33 \%\end{array}$ & Buruk & $\begin{array}{l}\text { Sangat } \\
\text { Baik }\end{array}$ \\
\hline 3 & $\begin{array}{l}\text { Pemahaman tentang pentingnya } \\
\text { penerapan model-model } \\
\text { pembelajaran inovatif }\end{array}$ & $\begin{array}{l}\text { Paham/Jelas } \\
50,00 \%\end{array}$ & $\begin{array}{l}\text { Paham/Jelas } \\
\quad 83,33 \%\end{array}$ & Buruk & $\begin{array}{c}\text { Sangat } \\
\text { Baik }\end{array}$ \\
\hline 4 & $\begin{array}{l}\text { Pemahaman tentang karakteristik } \\
\text { model-model pembelajaran } \\
\text { inovatif }\end{array}$ & $\begin{array}{c}\text { Paham/Jelas } \\
16,67 \%\end{array}$ & $\begin{array}{c}\text { Paham/Jelas } \\
16,67 \%\end{array}$ & $\begin{array}{l}\text { Sangat } \\
\text { Buruk }\end{array}$ & Baik \\
\hline 5 & $\begin{array}{l}\text { Pemahaman tentang } \\
\text { pelaksanaan model-model } \\
\text { pembelajaran inovatif yang dapat } \\
\text { memperkuat pendekatan saintifik } \\
5 \mathrm{M}\end{array}$ & $\begin{array}{c}\text { Paham/Jelas } \\
16,67 \%\end{array}$ & $\begin{array}{c}\text { Paham/Jelas } \\
83,33 \%\end{array}$ & $\begin{array}{l}\text { Sangat } \\
\text { Buruk }\end{array}$ & $\begin{array}{l}\text { Sangat } \\
\text { Baik }\end{array}$ \\
\hline 6 & $\begin{array}{l}\text { Pemahaman tentang pentingnya } \\
\text { peranan strategi conceptual } \\
\text { change dalam penerapan model- } \\
\text { model pembelajaran inovatif }\end{array}$ & $\begin{array}{c}\text { Paham } / \text { Jelas } \\
0,00 \%\end{array}$ & $\begin{array}{c}\text { Paham/Jelas } \\
66,67 \%\end{array}$ & $\begin{array}{l}\text { Sangat } \\
\text { Buruk }\end{array}$ & Baik \\
\hline
\end{tabular}

Berdasarkan Tabel 1 terlihat bahwa pada hasil pretes, hanya sedikit guru yang memahami tentang pengertian strategi conceptual change, pengertian model-model pembelajaran inovatif, pentingnya penerapan model-model pembelajaran inovatif, karakteristik model-model pembelajaran inovatif, dan pelaksanaan model-model pembelajaran inovatif yang dapat memperkuat pendekatan saintifik $5 \mathrm{M}$. Bahkan, tidak satupun guru memahami tentang pentingnya peranan strategi conceptual change dalam penerapan modelmodel pembelajaran inovatif. Namun, setelah pelatihan integrasi strategi Conceptual Change dalam model-model pembelajaran inovatif, menunjukkan bahwa semua guru telah memahami tentang pengertian strategi conceptual change. Materi model-model pembelajaran inovatif dan karakteristik model-model pembelajaran inovatif juga telah dipahami oleh sebagian besar guru dengan jelas. Demikian pula, pelaksanaan modelmodel pembelajaran inovatif yang dapat memperkuat pendekatan saintifik $5 \mathrm{M}$ juga telah dipahami oleh sebagian besar guru dengan jelas. Selain itu, sebagian besar guru juga memahami relevansi materi pelatihan dengan tugas mengajarnya yang mewujudkan pentingnya penerapan modelmodel pembelajaran inovatif dan sebagian besar guru sangat yakin bahwa strategi conceptual change berperan penting dalam penerapan model-model pembelajaran inovatif.

Hasil kemampuan guru MGMP Kimia di Kabupaten Blitar dalam menyusun kegiatankegiatan pembelajaran berbasis integrasi strategi Conceptual Change dalam model pembelajaran inovatif diperoleh melalui data hasil penyusunan RPP secara berkelompok. Hasil penilaian kemampuan guru menyusun kegiatan-kegiatan pembelajaran berbasis berbasis integrasi strategi Conceptual Change dalam model pembelajaran inovatif disajikan pada Tabel 2. 
Tabel 2. Kemampuan Menyusun Kegiatan-Kegiatan Pembelajaran

Berbasis Model Pembelajaran Inovatif

\begin{tabular}{clcc}
\hline No. & \multicolumn{1}{c}{ Komponen RPP } & Nilai & Kategori \\
\hline 1 & Perumusan indikator dan tujuan pembelajaran & 93,8 & $\begin{array}{c}\text { Sangat } \\
\text { Baik }\end{array}$ \\
\hline 2 & Pemilihan materi pembelajaran & 93,8 & $\begin{array}{c}\text { Sangat } \\
\text { Baik }\end{array}$ \\
\hline 3 & Pengorganisasian materi pembelajaran & 87,5 & $\begin{array}{c}\text { Sangat } \\
\text { Baik }\end{array}$ \\
\hline 4 & Pemilihan sumber belajar/media pembelajaran & 93,8 & $\begin{array}{c}\text { Sangat } \\
\text { Baik }\end{array}$ \\
\hline 5 & Skenario pembelajaran & 93,8 & $\begin{array}{c}\text { Sangat } \\
\text { Baik }\end{array}$ \\
\hline 6 & Penilaian & 81,3 & Baik \\
\hline 7 & Penggunaan bahasa tulis & 75,0 & Baik \\
\hline
\end{tabular}

Tabel 2 menunjukkan bahwa kemampuan peserta pelatihan dalam menyusun kegiatankegiatan pembelajaran berbasis integrasi strategi Conceptual Change dalam model pembelajaran inovatif pada masing-masing komponen telah memperoleh kategori sangat baik dan baik. Pada komponen perumusan indikator dan tujuan pembelajaran dalam pembuatan RPP telah memperoleh kategori sangat baik, yang berarti rumusan dan perjenjangan indikator dan tujuan telah jelas, serta telah sesuai dengan kompetensi dasar.

Kategori sangat baik pada komponen pemilihan dan pengorganisasian materi pembelajaran, ditunjukkan dengan kesesuaian materi dengan kompetensi yang akan dicapai dan karakteristik peserta didik, serta sistematika materi yang disajikan telah runtut dan sesuai dengan alokasi waktu. Kategori sangat baik pada komponen pemilihan sumber belajar/media pembelajaran ditunjukkan dengan kesesuaian sumber belajar/media pembelajaran dengan kompetensi yang akan dicapai, materi pembelajaran, model dan strategi pembelajaran serta karakteristik peserta didik. Demikian pula, kategori sangat baik pada skenario pembelajaran ditunjukkan dengan kelengkapan dan kejelasan langkahlangkah pembelajaran, serta kesesuaian jenis kegiatan pembelajaran dengan kompetensi.

Kategori baik pada komponen penilaian ditunjukkan oleh kesesuaian penilaian dengan kompetensi yang akan dicapai, kejelasan prosedur, kelengkapan instrument, dan kualitas instrument. Demikian pula, kategori baik pada komponen penggunaan Bahasa tulis ditunjukkan oleh ketepatan ejaan, ketepatan pilihan kata, dan kebakuan struktur kalimat.

Berdasarkan uraian di atas, didapatkan beberapa temuan sebagai berikut.

1. Kegiatan-kegiatan pembelajaran dalam RPP berbasis integrasi strategi Conceptual Change dalam model-model pembelajaran inovatif yang disusun guru adalah baik dan sangat baik. Hal tersebut mengindikasikan bahwa guru telah mampu mengintegrasikan strategi Conceptual Change dalam model-model pembelajaran inovatif dalam pengembangan RPP.

2. Perangkat pendukung RPP seperti Lembar Kegiatan Siswa (LKS), lembar asesmen, dan slide power point yang disusun guru adalah baik. Hal ini berarti guru telah mampu mengembangkan perangkat pendukung RPP dengan mengintegrasikan strategi Conceptual Change dalam model-model pembelajaran inovatif.

Angket tentang respon peserta ini diisi peserta setelah kegiatan pelaksanaan pelatihan model-model pembelajaran inovatif. Rekapitulasi respon peserta terhadap pelaksanaan pelatihan integrasi strategi Conceptual Change dalam model-model pembelajaran inovatif disajikan pada Tabel 3. 
Tabel 3. Respon Positif Peserta terhadap Pelatihan Integrasi Strategi Conceptual Change dalam Model-Model Pembelajaran Inovatif

\begin{tabular}{|c|c|c|c|}
\hline No. & Uraian & Respnom & Kategori \\
\hline 1 & Materi pelatihan & $\begin{array}{l}\text { Menarik } \\
100 \%\end{array}$ & $\begin{array}{l}\text { Sangat } \\
\text { Baik }\end{array}$ \\
\hline 2 & $\begin{array}{l}\text { Kompetensi narasumber terhadap materi yang menjadi } \\
\text { tanggung jawabnya }\end{array}$ & $\begin{array}{c}\text { Memadai } \\
100 \%\end{array}$ & $\begin{array}{c}\text { Sangat } \\
\text { Baik }\end{array}$ \\
\hline 3 & $\begin{array}{l}\text { Penyampaian materi pelatihan oleh narasumber efektif dan } \\
\text { menarik }\end{array}$ & $\begin{array}{c}\text { Ya } \\
66,67 \%\end{array}$ & Baik \\
\hline 4 & $\begin{array}{l}\text { Terdapat relevansi materi pelatihan dengan tugas mengajar } \\
\text { guru serta bersesuaian dengan kurikulum sekolah }\end{array}$ & $\begin{array}{c}\mathrm{Ya} \\
100 \% \\
\end{array}$ & $\begin{array}{l}\text { Sangat } \\
\text { Baik }\end{array}$ \\
\hline 5 & $\begin{array}{l}\text { Model-model pembelajaran inovatif berbasis } \\
\text { penyingkapan/penelitian (discovery/inquiry learning), } \\
\text { pembelajaran berbasis proyek (project based learning), dan } \\
\text { pembelajaran berbasis pemecahan masalah (problem } \\
\text { based learning) dapat diterapkan sesuai karakteristik mapel } \\
\text { kimia }\end{array}$ & $\begin{array}{c}\text { Ya } \\
66,67 \%\end{array}$ & Baik \\
\hline 6 & $\begin{array}{l}\text { Strategi conceptual change dapat diintegrasikan pada } \\
\text { semua model pembelajaran inovatif }\end{array}$ & $\begin{array}{c}\mathrm{Ya} \\
50,00 \%\end{array}$ & $\begin{array}{l}\text { Cukup } \\
\text { Baik }\end{array}$ \\
\hline 7 & $\begin{array}{l}\text { Keefektifan integrasi conceptual change dalam model- } \\
\text { model pembelajaran inovatif terhadap keterampilan berpikir } \\
\text { peserta didik }\end{array}$ & $\begin{array}{l}\text { Efektif } \\
66,67 \%\end{array}$ & Baik \\
\hline 8 & $\begin{array}{l}\text { Integrasi conceptual change dalam model-model } \\
\text { pembelajaran inovatif dapat membantu peserta didik untuk } \\
\text { memahami konsep-konsep kimia dan melatihkan } \\
\text { pemecahan masalah dalam pembelajaran di kelas }\end{array}$ & $\begin{array}{l}\text { Membantu } \\
88,33 \%\end{array}$ & $\begin{array}{l}\text { Sangat } \\
\text { Baik }\end{array}$ \\
\hline 9 & $\begin{array}{l}\text { Integrasi conceptual change dalam model-model } \\
\text { pembelajaran inovatif dapat berpengaruh terhadap hasil } \\
\text { belajar peserta didik }\end{array}$ & $\begin{array}{l}\text { Berpengaruh } \\
\quad 83,33 \%\end{array}$ & $\begin{array}{l}\text { Sangat } \\
\text { Baik }\end{array}$ \\
\hline
\end{tabular}

Berdasarkan data pada Tabel 3 terlihat bahwa hampir semua item respon memperoleh respon baik dan sangat baik. Semua guru kimia merespon bahwa materi pelatihan menarik, kompetensi narasumber terhadap materi yang menjadi tanggung jawabnya telah memadai, dan terdapat relevansi materi pelatihan dengan tugas mengajar guru serta bersesuaian dengan kurikulum sekolah.

Mayoritas guru kimia merespon bahwa penyampaian materi oleh Tim PKM menarik dan efektif, model-model pembelajaran inovatif dapat diterapkan sesuai karakteristik mapel kimia, dan integrasi conceptual change dalam model-model pembelajaran inovatif terhadap keterampilan berpikir peserta didik telah efektif.

Untuk item 'Strategi conceptual change dapat diintegrasikan pada semua modelmodel pembelajaran inovatif' masih mendapatkan kategori cukup baik. Hal tersebut dikarenakan bahwa guru-guru belum terbiasa mengintegrasikan strategi conceptual change dalam pembelajaran. Namun, para guru yakin bahwa integrasi conceptual change dalam model-model pembelajaran inovatif dapat membantu peserta didik untuk memahami konsepkonsep kimia dan melatihkan pemecahan masalah dalam pembelajaran di kelas dalam rangka memperbaiki miskonsepsi peserta didik, serta berpengaruh terhadap hasil belajar peserta didik.

\section{SIMPULAN DAN SARAN}

Berdasarkan tujuan dan hasil pelatihan yang telah diuraikan dapat disimpulkan seperti berikut ini.

1. Pemahaman materi integrasi strategi Conceptual Change dalam model-model pembelajaran inovatif guru MGMP kimia di Kabupaten Blitar telah memperoleh kategori baik dan sangat baik.

2. Kemampuan guru MGMP kimia di Kabupaten Blitar dalam menyusun kegiatan-kegiatan pembelajaran berbasis integrasi strategi Conceptual Change dalam model-model pembelajaran inovatif adalah baik dan sangat baik. 
3. Secara umum respon guru MGMP kimia di Kabupaten Blitar terhadap kegiatan pelatihan integrasi strategi Conceptual Change dalam model-model pembelajaran inovatif adalah baik dan sangat baik.

Kegiatan ini hendaknya dapat ditindak lanjuti, sebagai berikut.

1. Perlu melanjutkan rencana kegiatan PKM tahap berikutnya yaitu mengimplementasikan hasil penyusunan RPP yang mengintegrasikan strategi Conceptual Change dalam model-model pembelajaran inovatif.

Menyediakan contoh-contoh instrumen pengamatan dalam rangka implementasi hasil penyusunan RPP yang mengintegrasikan strategi Conceptual Change dalam model-model pembelajaran inovatif.

\section{DAFTAR PUSTAKA}

Cakir, M. (2008). Constructivist approaches to learning in science and their implication for science pedagogy: a literature review. International Journal of Environmental \& Science Education. 3(4). 193-206.

Undang-Undang Nomor 20 Tahun 2003 tentang Sistem Pendidikan Nasional

Peraturan Menteri Pendidikan dan Kebudayaan Republik Indonesia Nomor 22 Tahun 2016 tentang Standar Proses pada Pendidikan Dasar dan Pendidikan Menengah.

Rohman, M. (2012). Kurikulum Berkarakter: Refleksi dan Proposal Solusi terhadap KBK dan KTSP. Jakarta: Prestasi Pustakaraya.

Undang-Undang Nomor 20 Tahun 2003 tentang Sistem Pendidikan Nasional

Wagiran. (2007). Inovasi Pembelajaran dalam Penyiapan tenaga Kerja Masa Depan. Jurnal Pendidikan Teknologi \& Kejuruan. 16(1): 43-55. 